\title{
Sulforaphane inhibits the growth of KPL-1 human breast cancer cells in vitro and suppresses the growth and metastasis of orthotopically transplanted KPL-1 cells in female athymic mice
}

\author{
SAYAKA KANEMATSU, KATSUHIKO YOSHIZAWA, NORIHISA UEHARA, HISANORI MIKI, \\ TOMO SASAKI, MAKI KURO, YEN-CHANG LAI, AYAKO KIMURA, TAKASHI YURI and AIRO TSUBURA
}

Department of Pathology II, Kansai Medical University, Moriguchi, Osaka 570-8506, Japan

Received February 10, 2011; Accepted April 20, 2011

DOI: 10.3892/or.2011.1311

\begin{abstract}
The anticancer effects of sulforaphane (SFN), which is found in cruciferous vegetables, were studied on KPL-1 human breast cancer cells in vitro and in vivo. Cell proliferation in vitro was assessed by a 3-(4,5-dimethylthiazol2-yl)-2,5-diphenyltetrazolium bromide (MTT) assay, and tumor growth and metastasis in vivo were examined in orthotopically (right thoracic mammary fat pad) transplanted KPL-1 cells in female athymic BALB/c mice. The MTT assay showed that SFN directly inhibited KPL-1 cell growth in vitro $\left(\mathrm{IC}_{50}\right.$ at $48 \mathrm{~h}, 19.1 \mu \mathrm{M} ; \mathrm{IC}_{50}$ at $\left.72 \mathrm{~h}, 17.8 \mu \mathrm{M}\right)$. Athymic mice received a KPL-1 cell transplant, and SFN treatment (intraperitoneal injection of 25 or $50 \mathrm{mg} / \mathrm{kg}$ SFN) was started the next day. Mice received five injections each week during the 26-day experimental period (for a total of 20 injections). Compared with the SFN-untreated controls, SFN suppressed primary tumor growth. At the termination of the experiment, the final tumor volume was $686 \pm 94 \mathrm{~mm}^{3}$ for the control group, $516 \pm 70 \mathrm{~mm}^{3}$ (75\% of control value) for the $25 \mathrm{mg} / \mathrm{kg}$ SFN group and $351 \pm 55 \mathrm{~mm}^{3}$ (51\% of control value) for the $50 \mathrm{mg} / \mathrm{kg}$ SFN group. The final tumor weight was $571 \pm 69 \mathrm{mg}$ in the control group, $416 \pm 63 \mathrm{mg}$ ( $73 \%$ of the control value) in the $25 \mathrm{mg} / \mathrm{kg}$ SFN group and $338 \pm 56 \mathrm{mg}$ (59\% of the control value) in the $50 \mathrm{mg} / \mathrm{kg}$ SFN group. SFN caused a dosedependent decrease in the proliferation ratio and an increase in the apoptotic ratio of the primary tumor cells. SFN treatment tended to reduce regional (axillary) lymph node metastasis. Treatment with $50 \mathrm{mg} / \mathrm{kg}$ SFN significantly inhibited KPL-1 cell growth in vivo by suppressing cell proliferation and inducing apoptosis, and it tended to reduce axillary lymph node metastasis of KPL-1 human breast cancer cell xenografts in female athymic mice.
\end{abstract}

Correspondence to: Dr Airo Tsubura, Department of Pathology II, Kansai Medical University, Moriguchi, Osaka 570-8506, Japan

E-mail: tsubura@takii.kmu.ac.jp

Key words: apoptosis, athymic mouse, breast cancer, cell kinetics, KPL-1, metastasis, sulforaphane

\section{Introduction}

Breast cancer is one of the most common malignancies in women worldwide. It is estimated that each year there are more than one million new cases of breast cancer worldwide and 410,000 breast cancer-related deaths (1). Genetic susceptibility, hormonal effects, and environmental factors appear to be the major determinant of breast cancer. The incidence and mortality of breast cancer is 5 times higher in Western countries than in some Asian countries, and Asian migrants to the US eventually acquire the breast cancer incidence of the host country (2), which suggests the importance of environmental and lifestyle factors. It is generally thought that about one-third of cancers are related to dietary factors (3). Phytochemicals affect breast cancer, and some phytochemicals suppress the occurrence and progression of the disease (4).

Breast cancer risk is inversely associated with broccoli consumption (5). Sulforaphane [SFN; 1-isothiocyanato-4(methylsulfinyl)-butane; $\mathrm{CH}_{3}-\mathrm{SO}-\left(\mathrm{CH}_{2}\right)_{4}-\mathrm{N}=\mathrm{C}=\mathrm{S}$ ] (Fig. 1), which is a constituent of cruciferous vegetables such as broccoli and broccoli sprouts, displays anti-cancer activity against many cancers including breast cancer. In vitro experiments with cultured human cancer cells are valuable tools for rapid screening to identify potent anti-cancer action. SFN induces growth inhibitory effects against estrogen receptor (ER)-positive (MCF-7 and T47D) and ER-negative (MDAMB-231, MDA-MB-468, and SUM159) human breast cancer cell lines in vitro. The half maximal inhibitory concentration $\left(\mathrm{IC}_{50}\right)$ for $48 \mathrm{~h}$ in MCF-7 and SUM159 cells was determined to be $\sim 1$ and $10 \mu \mathrm{M}$, respectively (6). The $\mathrm{IC}_{50}$ for $72 \mathrm{~h}$ in one study for MCF-7, T47D, MDA-MB-231, and MDA-MB-468 cells was 9.2, 9.5, 8.3, and 8.1 $\mu \mathrm{M}$, respectively (7); in another study, the $\mathrm{IC}_{50}$ for $72 \mathrm{~h}$ for MCF-7 and MDA-MB-231 cells was 33.8 and $31.5 \mu \mathrm{M}$, respectively (8). Moreover, SFN more effectively inhibits the growth of MCF-7 human breast cancer cells than MCF-12A normal human breast epithelial cells ( $\mathrm{IC}_{50}$ for $48 \mathrm{~h}$ is $27.9 \mu \mathrm{M}$ vs. $40.5 \mu \mathrm{M}$, respectively) (9). SFN inhibits the proliferation of human breast cancer cells at concentrations that have negligible effects on normal breast epithelial cells (10). In vitro experiments have shown that SFN causes cell-cycle arrest in S and G2/M that is associated with increased $\mathrm{p} 21^{\mathrm{WAF} 1}$ and $\mathrm{p} 27^{\mathrm{KIP} 1}$ levels and decreased cyclin A, 


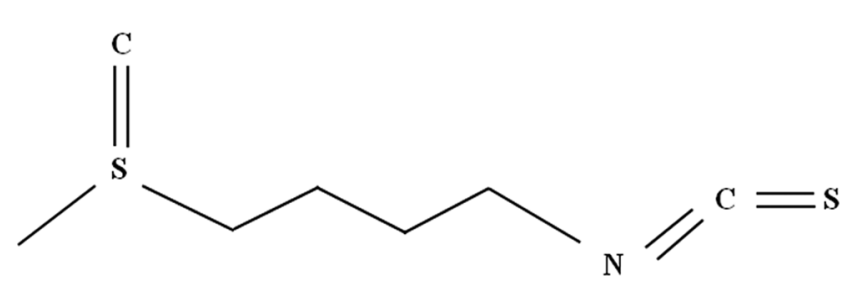

Figure 1. Chemical structure of sulforaphane.

cyclin B1 and Cdc2 levels and that SFN causes apoptosis with increased caspase-3 and lowered Bcl-2 (8). Interestingly, autophagy functions as a cell protective mechanism and autophagy inhibition enhances SFN-induced apoptosis in human breast cancer cells (8).

The mortality of breast cancer depends on its invasion and metastatic potential. Cancer cells dissociate from the primary site, enter the lymphatics and/or bloodstream, and re-attach at secondary sites. The acquisition of the metastatic phenotype is associated with the down-regulation of adhesion molecules, increased matrix metalloproteinase (MMP) expression, and increased angiogenesis. For identification of the anticancer potential of SFN the in vivo effects of SFN in a suitable animal model should be assessed. The dosage of the test chemical must be set within the range of doses that do not cause side-effects. Orthotopic (within the right thoracic mammary fat pad) KPL-1 cell transplantation in athymic mice causes rapid primary tumor growth at the inoculation site and the development of regional (axillary) lymph node metastasis (11-15). In the present study, the effects of SFN on KPL-1 cells were assessed in vitro. Then, the effects of SFN on growth and metastasis of KPL-1 xenografts was examined, and the general condition of the host animals was evaluated.

\section{Materials and methods}

Cell line. KPL-1 is a human breast cancer cell line established from the malignant effusion of a breast cancer patient (16). The ER-positive KPL-1 cell line is estrogen-independent, grows rapidly in female athymic mice, and often develops regional (axillary) lymph node metastasis in such mice when inoculated orthotopically (within the thoracic mammary fat pad) (11-15). KPL-1 cells were maintained in Dulbecco's modified Eagle's medium (DMEM; Sigma, St. Louis, MO) with 10\% fetal bovine serum (FBS; Gibco-BRL, Grand Island, $\mathrm{NY}$ ) in $5 \% \mathrm{CO}_{2} / 95 \%$ humidified air at $37^{\circ} \mathrm{C}$.

Chemicals. D,L-SFN (purity $>99.5 \%$ ) was obtained from LKT Laboratories (St. Paul, MN, USA). A stock solution of SFN (1 M) was prepared using dimethyl sulfoxide (DMSO, Nacalai Tesque, Kyoto, Japan) as a solvent and stored at $-30^{\circ} \mathrm{C}$ in the dark. The stock SFN solution was diluted with PBS at a concentration of $0.1 \mathrm{M}$ just before use.

In vitro cell proliferation assay. Cells were seeded at $2 \times 10^{3}$ cell/well in 96-well plates in growth medium supplemented with $10 \%$ fetal bovine serum (FBS). The cells were treated with DMSO or the indicated concentrations of SFN for up to $72 \mathrm{~h}$. Cell proliferation was monitored by the 3-(4,5-dimethyl-
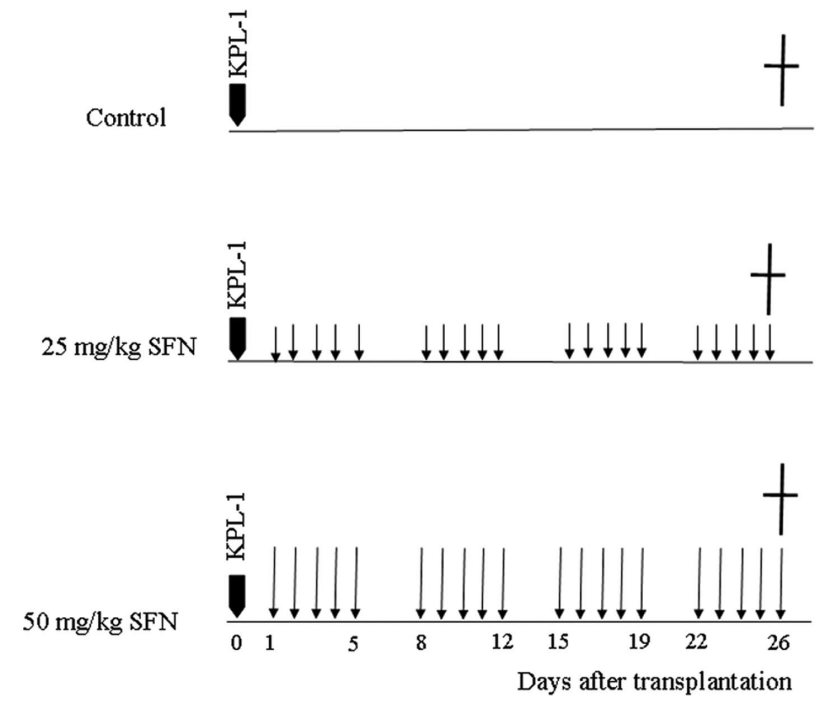

Figure 2. Schematic representation of the experimental protocol.

thiazol-2-yl)-2,5-diphenyltetrazolium bromide (MTT) assay, as described previously (8).

Orthotopic KPL-1 cell transplantation. Thirty 5-week-old female athymic BALB/c mice purchased from Charles River Japan (Kyoto) were used as host animals. Animals were housed in groups of five in plastic cages with paper bedding (Paper Clean, SLC, Hamamatsu, Japan) in a specific pathogen-free room maintained at $22 \pm 2^{\circ} \mathrm{C}$ and $60 \pm 10 \%$ relative humidity with a 12-h light/dark cycle (lights on at 8:00 am and lights off at 8:00 pm). Animals were maintained on a commercial pellet diet (CMF $30 \mathrm{kGy}$, Oriental Yeast, Chiba, Japan) and had free access to water. After a 1-week acclimatization period, when mice were 6 weeks of age, a suspension of $1 \times 10^{7}$ viable KPL-1 cells in $100 \mu$ l DMEM supplemented with $10 \%$ FBS was injected into the right thoracic mammary fat pad with a 26 -gauge needle. Mice were randomly divided into three groups $(25 \mathrm{mg} / \mathrm{kg} \mathrm{SFN}$-treated, $50 \mathrm{mg} / \mathrm{kg}$ SFN-treated, and SFN-untreated groups), and each group contained 10 mice (Fig. 2). One day after KPL-1 transplantation, the mice received their first intraperitoneal (i.p.) injection of SFN or vehicle. The injections were repeated each day for 5 days followed by two drug holidays for a total of 4 weeks (until the termination of the experiment). The mice were weighed every day, and locally growing tumor volumes were measured every 3 days. Tumor volume was calculated by using the standard formula: width $^{2}$ $\mathrm{x}$ length $\mathrm{x} 0.5$. Twenty-six days after tumor cell inoculation, the mice were weighed and then killed by exsanguination from aortic transection. The size and weight of the locally growing tumors were then determined. At autopsy, all organs were examined macroscopically, and the primary tumors and regional (axillary) lymph nodes were examined histologically. Tissues were fixed in $10 \%$ neutral buffered formalin, embedded in paraffin, and stained with hematoxylin and eosin (H\&E). In addition, the presence of metastatic foci was confirmed by pan-cytokeratin immunohistochemistry with anti-human cytokeratin antibody (clone AE1/AE3, Dako, Glostrup, Denmark) and a labeled streptavidin-biotin (LSAB) staining kit (Dako, Carpinteria, CA, USA). The effects of treatments 
are represented as the $\mathrm{T} / \mathrm{C} \%$ calculated by the formula [Mean tumor volume (or weight) at the termination of the experiment in the treated group/(mean tumor volume (or weight) at the termination of the experiment in the control group)] x 100. All animals were cared for in accordance with the Guidelines for Animal Experimentation of Kansai Medical University. The study protocol was approved by an institutional review board.

Ki-67 immunohistochemistry and TUNEL staining. The cell kinetics (cell proliferation and cell death) in primary tumors were evaluated. Cell proliferation was evaluated by Ki-67 immunohistochemistry with anti-Ki-67 antibody (clone MIB1, Dako, Glostrup, Denmark) and an LSAB staining kit. Cell death was evaluated by TdT-mediated dUTP-digoxigenin nick end-labeling (TUNEL) performed with an in situ apoptosis detection kit (Apop-Tag, Millipore, Billerica, MA, USA). The respective positive signals were visualized by 3,3'-diaminobenzidine (DAB). For quantitative analysis, Ki-67-stained and TUNEL-labeled tumor sections, respectively, were scanned with a high-resolution digital slide scanner (NanoZoomer 2.0 Digital Pathology, Hamamatsu Photonics, Hamamatsu, Japan) to prepare digital images. The ndpi image files were opened in color mode with NDP.view software (Hamamatsu Photonics). These image figures were changed to tiff files at x40 magnification in three randomly selected areas. By using Adobe Photoshop CS2 software (Adobe Systems, Tokyo, Japan), the Ki-67-positive and TUNEL-positive cell numbers in the tumor areas were individually measured. Morphometric evaluations of the number of Ki-67-positive and TUNELpositive cells per $1 \mathrm{~mm}^{2}$, respectively, were performed by two pathologists certified by the Japanese Society of Toxicologic Pathology (K.Y. and A.T.).

Statistical analysis. All values are expressed as the mean \pm standard error of the mean (SEM). Body weight, tumor volume, tumor weight, and the number of $\mathrm{Ki}-67$-positive and TUNEL-positive cells per $1 \mathrm{~mm}^{2}$ among the groups were analyzed by one-way ANOVA followed by the Dunnett's test. The incidence of metastasis was analyzed with the $\chi^{2}$ test. A probability value of $\mathrm{p}<0.05$ was considered statistically significant.

\section{Results}

In vitro cell growth inhibition. KPL-1 cells were treated with several concentrations (1-100 $\mu \mathrm{M})$ of SFN for up to $72 \mathrm{~h}$. The MTT assay revealed that SFN induced growth inhibition in a dose- and time-dependent manner (Fig. 3). The $\mathrm{IC}_{50}$ against KPL-1 cells was $19.1 \pm 1.4 \mu \mathrm{M}$ after a 48 -h treatment and $17.8 \pm 0.6 \mu \mathrm{M}$ after a $72-\mathrm{h}$ treatment.

Host animals. The average body weight of mice treated with 25 or $50 \mathrm{mg} / \mathrm{kg}$ SFN was slightly lower than that of the control mice throughout the treatment period. However, the difference in body weight was not statistically significant, and the 25 and $50 \mathrm{mg} / \mathrm{kg}$ SFN treatments caused no weight loss during the experimental period (Fig. 4).

In vivo primary tumor growth. The tumors at the inoculation sites grew most rapidly in the control group, followed by the

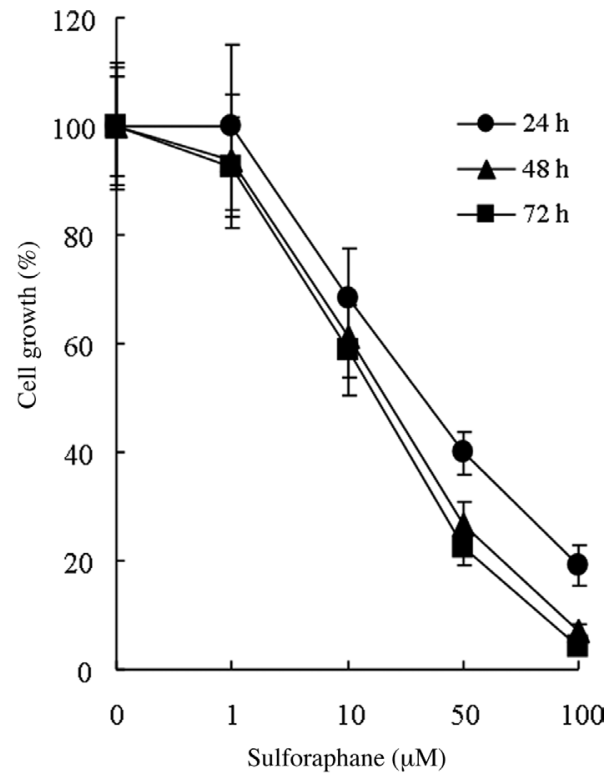

Figure 3. Effects of sulforaphane on in vitro cell proliferation. DMSO control and SFN-treated KPL-1 cells were plated on 96-well plates at $2 \times 10^{3}$ cells/well, and cell proliferation was determined by the MTT assay. Data are the mean \pm SEM of 3 independent experiments.

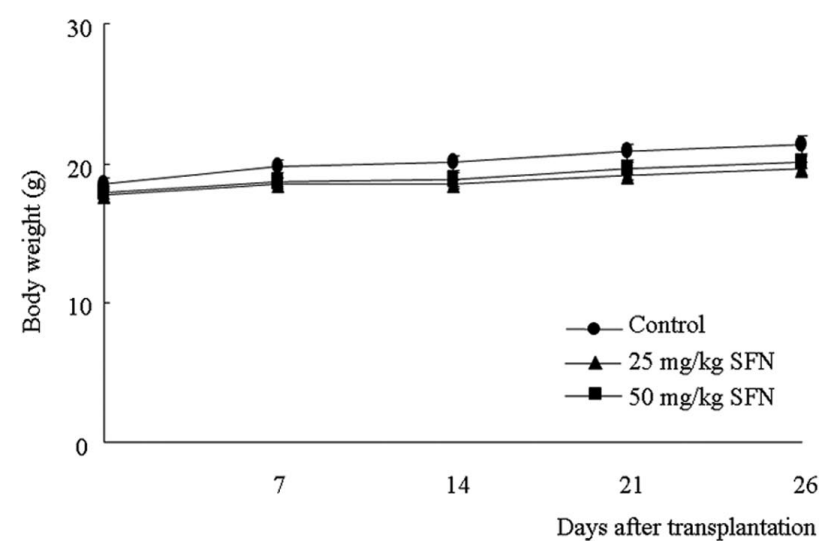

Figure 4. Effects of sulforaphane on body weight change in female athymic $\mathrm{BALB} / \mathrm{c}$ mice.

$25 \mathrm{mg} / \mathrm{kg}$ SFN group and then the $50 \mathrm{mg} / \mathrm{kg}$ SFN group. Thus, SFN dose-dependently suppressed the growth of KPL-1 cells (Fig. 5a). At 17, 23, and 26 days after KPL-1 inoculation, the tumor volumes in $50 \mathrm{mg} / \mathrm{kg}$ SFN-treated mice were significantly reduced compared to the control group. The tumor volumes at the termination of the experiment were $686 \pm 94 \mathrm{~mm}^{3}$ in the control group, $516 \pm 70 \mathrm{~mm}^{3}$ (75\% of the control group volume) in the $25 \mathrm{mg} / \mathrm{kg}$ SFN group, and $351 \pm 55 \mathrm{~mm}^{3}$ ( $51 \%$ of the control group volume) in the $50 \mathrm{mg} / \mathrm{kg}$ SFN group. The tumor weights at the termination of the experiment were $571 \pm 69 \mathrm{mg}$ in the control group, $416 \pm 63 \mathrm{mg}$ (73\% of the control group weight) in the $25 \mathrm{mg} / \mathrm{kg}$ SFN group, and $338 \pm 56 \mathrm{mg}$ (59\% of the control group weight) in the $50 \mathrm{mg} / \mathrm{kg}$ SFN group. Both the tumor volume and tumor weight in the $50 \mathrm{mg} / \mathrm{kg}$ SFN group were significantly smaller $(p<0.01$ and $p<0.05$, respectively) than those of the control group (Fig. 5a and b). 

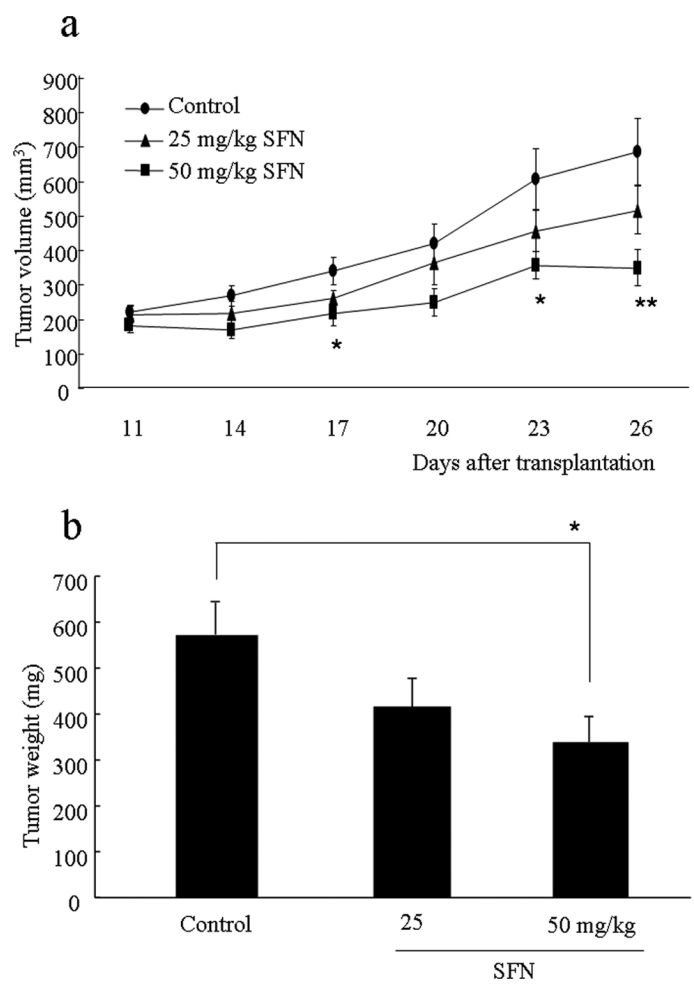

Figure 5. Effects of sulforaphane on the primary tumor growth of KPL-1 cells at the inoculation site. (a) Significant differences in tumor volume were noted after treatment with $50 \mathrm{mg} / \mathrm{kg} \mathrm{SFN}$; "p $<0.05$ (days 17 and 23) and ${ }^{* *} \mathrm{p}<0.01$ (day 26) vs. control. (b) A significant difference in the final tumor weight was determined for $50 \mathrm{mg} / \mathrm{kg}$ SFN vs. control $(\mathrm{p}<0.05)$.
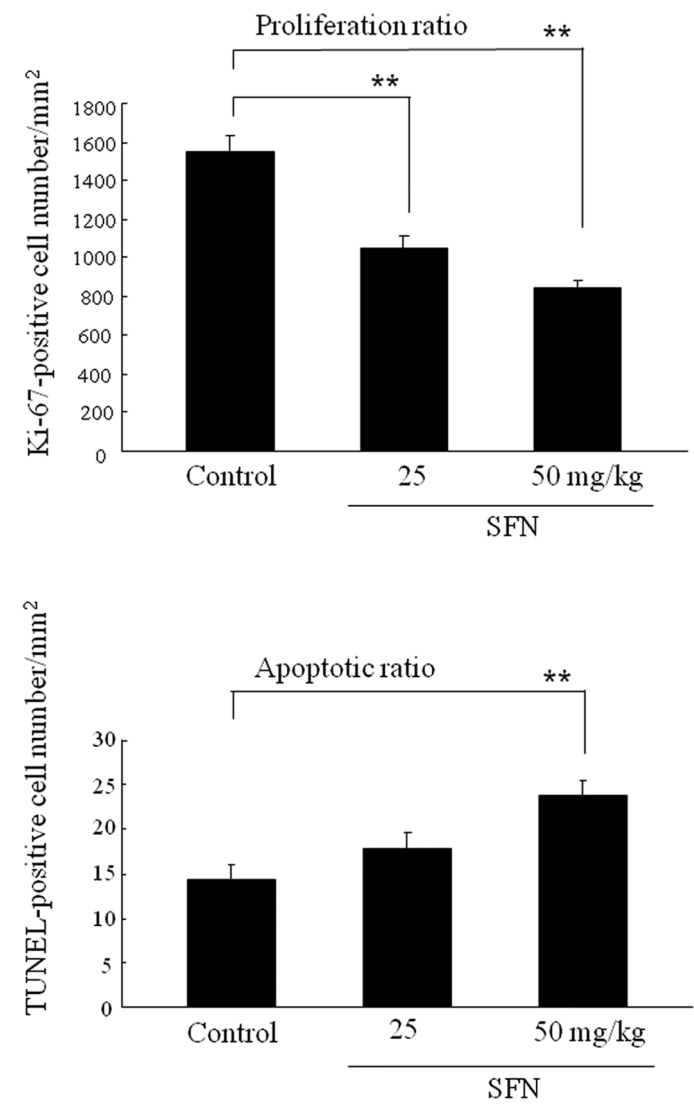

Figure 6. Effects of sulforaphane on cell kinetics in KPL-1 tumors in female athymic $\mathrm{BALB} / \mathrm{c}$ mice at the termination of the experiment. ${ }^{* *} \mathrm{p}<0.01 \mathrm{vs}$. controls.

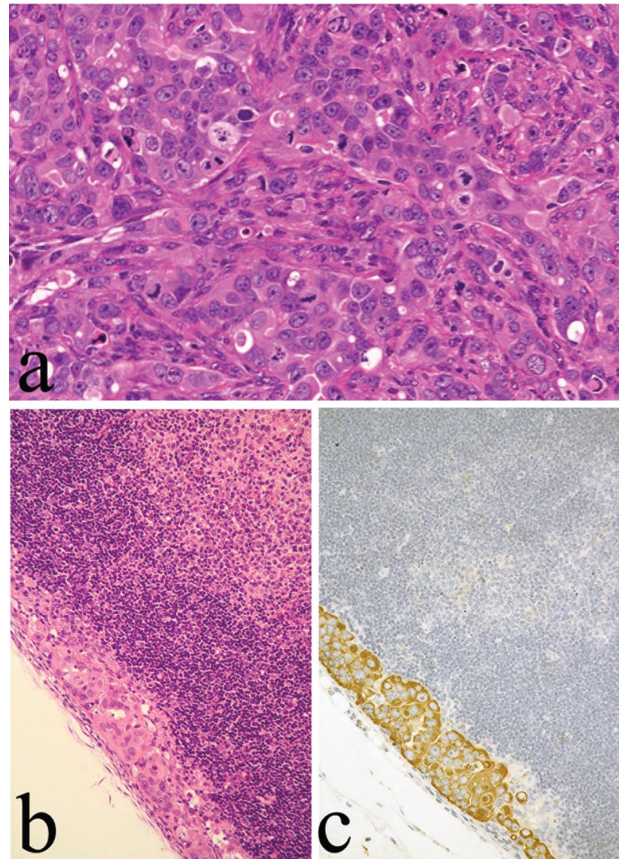

Figure 7. KPL-1 tumor in the mammary fat pad of a female athymic BALB/c mouse. (a) The locally growing tumor was composed of polygonal cells possessing round or oval nuclei and conspicuous nucleoli with frequent mitotic figures (H\&E). (b) KPL-1 cells metastasized to the marginal sinus of the regional (axillary) lymph node (H\&E). (c) Metastatic KPL-1 cells are clearly labeled with pan-cytokeratin (AE1/AE3).

Table I. Effects of sulforaphane on regional lymph node metastasis after KPL-1 cell inoculation into thoracic mammary fat pads of female BALB/c athymic mice.

\begin{tabular}{lccc}
\hline Treatment & $\begin{array}{c}\text { No. of } \\
\text { mice }\end{array}$ & $\begin{array}{c}\text { No. of mice with } \\
\text { metastasis }(\%)\end{array}$ & $\begin{array}{c}\text { P-value } \\
\text { vs. control }\end{array}$ \\
\hline Control & 10 & $5(50)$ & - \\
$25 \mathrm{mg} / \mathrm{kg} \mathrm{SFN}$ & 10 & $1(10)$ & 0.051 \\
$50 \mathrm{mg} / \mathrm{kg} \mathrm{SFN}$ & 9 & $1(11)$ & 0.068
\end{tabular}

SFN, sulforaphane. One mouse from the $50 \mathrm{mg} / \mathrm{kg}$ SFN-treated group was excluded from the calculation because lymph nodes could not be obtained at the time of sacrifice.

Proliferation and apoptotic ratio. To compare the tumor cell kinetics (cell proliferation and cell death), the Ki-67-positive cell number and the TUNEL-positive cell number per $1 \mathrm{~mm}^{2}$ of primary tumors were determined. The proliferation and apoptotic ratios are shown in Fig. 6. The proliferation ratios in the control, $25 \mathrm{mg} / \mathrm{kg} \mathrm{SFN}$, and $50 \mathrm{mg} / \mathrm{kg}$ SFN groups were $1548 \pm 81,1049 \pm 61$, and $840 \pm 41$, respectively. Thus, the proliferation ratio was highest in the control group, and SFN dose-dependently decreased the proliferation. On the other hand, the apoptotic ratios in the control, $25 \mathrm{mg} / \mathrm{kg} \mathrm{SFN}$, and $50 \mathrm{mg} / \mathrm{kg}$ SFN groups were $14 \pm 2,18 \pm 2$, and $24 \pm 2$, respectively. Thus, the apoptotic ratio was lowest in the control group, and SFN dose-dependently increased the value. Although the different SFN doses caused different tumor cell kinetics as compared to the control group, all of the tumors showed 
identical poorly differentiated adenocarcinoma histology; the tumors were composed of polygonal cells possessing round or oval nuclei with conspicuous nucleoli and frequent mitotic figures (Fig. 7a). Almost all tumor cells were AE1/AE3 positive (data not shown).

Regional lymph node metastasis. The KPL-1 cells preferentially metastasized to the regional (axillary) lymph nodes (Fig. 7b). Micrometastases frequently seen at the peripheral sinus were clearly visualized by AE1/AE3 positivity (Fig. 7c). However, no remote metastasis was seen. The development of lymph node metastasis in each group is summarized in Table I. SFN tended to suppress axillary lymph node metastasis, although the tendency was not statistically significant.

\section{Discussion}

Previous in vitro studies have revealed that SFN effectively reduced the growth of both ER-positive and ER-negative human breast cancer cells (6-9). In agreement, the present study showed that SFN inhibits ER-positive KPL-1 human breast cancer cell growth in vitro with an $\mathrm{IC}_{50}$ of $19.1 \mu \mathrm{M}$ for $48 \mathrm{~h}$ and $17.8 \mu \mathrm{M}$ for $72 \mathrm{~h}$.

In the present in vivo study, i.p. administration of SFN (25 mg/kg or $50 \mathrm{mg} / \mathrm{kg}$ ) five times a week during the 26-day experimental period (a total of $20 \mathrm{SFN}$ injections), reduced KPL-1 cell growth and suppressed metastasis without causing adverse side effects. SFN did not cause body weight loss and did not significantly lower body weight. The higher dose of $\mathrm{SFN}$, which was $50 \mathrm{mg} / \mathrm{kg}$ (or $1.0 \mathrm{mg} /$ day for a $20 \mathrm{~g}$ athymic mouse), significantly suppressed the primary tumor growth. A previous study found that mice that received i.p. SFN at a dose of $500 \mu \mathrm{mol} / \mathrm{kg} /$ day $(1.77 \mathrm{mg} /$ day $)$ experienced a decreased activity level, and death occurred when the dose was further increased, while a dose of $375 \mu \mathrm{mol} / \mathrm{kg} /$ day $(1.33 \mathrm{mg} /$ day $)$ for 3 weeks was well tolerated (17). Daily i.p. injections of $50 \mathrm{mg} / \mathrm{kg}$ SFN for 2 weeks decreased ER-negative SUM159 human breast cancer cell growth in male SCID mouse xenografts and reduced the tumor size to $50 \%$ of control animals with no apparent toxicity (6). Daily i.p. injections of $375 \mu \mathrm{mol} / \mathrm{kg} / \mathrm{day}$ (1.33 mg/day) for 3 weeks in SCID mice inoculated with PANC-1 human pancreas cancer cells decreased mean tumor volume by $40 \%$ compared with controls (17). SFN at a dose of 1 or $2 \mathrm{mg} /$ day, 5 times a week for 4 weeks inhibited the growth of MG63 human osteosarcoma cells transplanted in male BALB/c mice to $<30 \%$ of the controls (18). SFN administered orally (p.o.) at a dose of $5.6 \mu \mathrm{mol}(0.99 \mathrm{mg} /$ day), 3 times a week for 20 days, reduced the androgen receptor-negative PC-3 human prostate cancer cell growth in male athymic mice, and the average tumor volume was $\sim 71 \%$ lower than controls (19). Similarly, an average daily dose of $7.5 \mu \mathrm{mol}$ (1.33 mg/day) of SFN for 21 days reduced the growth of PC-3 cells by $40 \%$ in male athymic mice (20). Therefore, SFN at $\sim 1 \mathrm{mg} /$ day significantly reduces the growth of various types of cancer cells transplanted in mice with no apparent side-effects.

In some reports, even lower doses of SFN are effective in suppressing the growth of tumor cells transplanted into mice. SFN p.o. at a dose of $50 \mu \mathrm{g} / \mathrm{kg}$ (750 $\mu \mathrm{g} /$ day) significantly decreased the tumor volume and final tumor weight of $\mathrm{KB}$ human oral squamous cell carcinoma cells in female athymic mice when compared with controls (21), and daily intravenous (i.v.) SFN at a dose of $15 \mathrm{nmol} /$ day (2.6 $\mu \mathrm{g} /$ day) for 14 days suppressed murine F3II mammary carcinoma cell growth in BALB/c mice ( $\sim 60 \%$ reduction in mass) (22). Thus, regardless of the origin of cancer cells and regardless of receptor status, SFN administered by various routes (i.p., p.o., or i.v.) effectively suppressed the growth of tumor cell transplants in animals. SFN inhibits prostate carcinogenesis in Transgenic Adenocarcinoma of Mouse Prostate (abbreviated as TRAMP) mice and inhibits orthotopically transplanted PC-3 cell growth in athymic mice by inhibiting cell proliferation and inducing apoptosis $(23,24)$. The balance between cell proliferation and apoptosis is crucial in determining the overall tumor growth or regression in response to therapy. In agreement, in the present in vivo study, SFN inhibited cell proliferation (as shown by a reduction in Ki67-positive cells) and induced apoptosis (as shown by an increase in TUNEL-positive cells) in KPL-1 tumors at the inoculation site.

Metastasis defines malignancy and is a major contributor to cancer mortality. SFN decreased VEGF-, CD31-, and factor VIII-positive cells (indicating the suppression of angiogenesis) and inhibited MMP-2, -7, and -9-positive cells (indicating the suppression of invasion and metastasis) in orthotopically transplanted PC-3 cells (23). Lung metastasis induced by B16F-10 melanoma cells injected into the tail vein of C57BL/6 mice was reduced by daily i.p. administration of $500 \mu \mathrm{g} / \mathrm{kg}$ SFN (10 $\mu \mathrm{g} /$ day) (25). In vitro studies revealed that the antimetastatic activity of SFN on B16F-10 cells was caused by the inhibition of MMP-2 and -9 activation. In the TRAMP mouse model, significant inhibition of lung metastasis by SFN was in accord with increased E-cadherin expression, which promotes cell-cell adhesion, and with low vessel density (24). Increased E-cadherin expression and reduced MMP expression indicates an inhibition of migration, adhesion, and invasion. In the present study, although it did not reach the level of statistical significance, SFN suppressed regional axillary lymph node metastasis, probably due to the involvement of one or more of these mechanisms.

In summary, i.p. administration of SFN dose-dependently reduced the primary tumor growth and suppressed regional axillary lymph node metastasis of human KPL-1 breast cancer cells in female athymic mice. The mechanisms of action were SFN-induced suppression of cell proliferation and acceleration of apoptosis. Therefore, SFN seems to be a good candidate for breast cancer control.

\section{Acknowledgements}

We thank Ms. T. Akamatsu for her technical assistance and Ms. A. Shudo for manuscript preparation. This study was supported in part by a Grant-in-Aid for Scientific Research (C) (21591683) from the Ministry of Education, Culture, Sports, Science and Technology of Japan, by a Health and Labor Science Research Grant for Research on Food Safety, and a grant from the Osaka Community Foundation.

\section{References}

1. Coughlin SS and Ekwueme DU: Breast cancer as a global health concern. Cancer Epidemiol 33: 315-318, 2009. 
2. Adami HO, Signorello LB and Trichopoulos D: Towards an understanding of breast cancer etiology. Semin Cancer Biol 8: 255-262, 1998.

3. Doll R and Peto R: The causes of cancer: quantitative estimates of avoidable risks of cancer in the United States today. J Nat Cancer Inst 66: 1191-1308, 1981.

4. Tsubura A, Uehara N, Kiyozuka Y and Shikata N: Dietary factors modifying breast cancer risk and relation to time of intake. J Mammary Gland Biol Neoplasia 10: 87-100, 2005.

5. Ambrosone CB, McCann SE, Freudenheim JL, Marshall JR, Zhang Y and Shields PG: Breast cancer risk in premenopausal women is inversely associated with consumption of broccoli, a source of isothiocyanates, but is not modified by GST genotype. J Nutr 134: 1134-1138, 2004.

6. Li Y, Zhang T, Korkaya H, Liu S, Lee HF, Newman B, Yu Y, Clouthier SG, Schwartz SJ, Wicha MS and Sun D: Sulforaphane, a dietary component of broccoli/broccoli sprouts, inhibits breast cancer stem cells. Clin Cancer Res 16: 2580-2590, 2010.

7. Pledgie-Tracy A, Sobolewski MD and Davidson NE: Sulforaphane induces cell type-specific apoptosis in human breast cancer cell lines. Mol Cancer Ther 6: 1013-1021, 2007.

8. Kanematsu S, Uehara N, Miki H, Yoshizawa K, Kawanaka A, Yuri T and Tsubura A: Autophagy inhibition enhances sulforaphane-induced apoptosis in human breast cancer cells. Anticancer Res 30: 3381-3390, 2010

9. Tseng E, Scott-Ramsay EA and Morris ME: Dietary organic isothiocyanates are cytotoxic in human breast cancer MCF-7 and mammary epithelial MCF-12A cell lines. Exp Biol Med (Maywood) 229: 835-842, 2004.

10. Meeran SM, Patel SN and Tollefsbol TO: Sulforaphane causes epigenetic repression of hTERT expression in human breast cancer cell lines. PLoS One 5: e11457, 2010.

11. Singh Y, Shikata N, Kiyozuka Y, Nambu H, Morimoto J, Kurebayashi J, Hioki K and Tsubura A: Inhibition of tumor growth and metastasis by angiogenesis inhibitor TNP-470 on breast cancer cell lines in vitro and in vivo. Breast Cancer Res Treat 45: 15-27, 1997.

12. Senzaki H, Iwamoto S, Ogura E, Kiyozuka Y, Arita S, Kurebayashi J, Takada H, Hioki K and Tsubura A: Dietary effects of fatty acids on growth and metastasis of KPL-1 human breast cancer cells in vivo and in vitro. Anticancer Res 18: 1621-1627, 1998.

13. Nakagawa H, Tsuta K, Kiuchi K, Senzaki H, Tanaka K, Hioki K and Tsubura A: Growth inhibitory effects of diallyl disulfide on human breast cancer cell lines. Carcinogenesis 22: 891-897, 2001.

14. Yuri T, Danbara N, Tsujita-Kyutoku M, Kiyozuka Y, Senzaki H, Shikata N, Kanzaki H and Tsubura A: Perillyl alcohol inhibits human breast cancer cell growth in vitro and in vivo. Breast Cancer Res Treat 84: 251-260, 2004.
15. Tsujita-Kyutoku M, Yuri T, Danbara N, Senzaki H, Kiyozuka Y, Uehara N, Takada H, Hada T, Miyazawa T, Ogawa Y and Tsubura A: Conjugated docosahexaenoic acid suppresses KPL-1 human breast cancer cell growth in vitro and in vivo: potential mechanisms of action. Breast Cancer Res 6: R291-R299, 2004.

16. Kurebayashi J, Kurosumi M and Sonoo H: A new human breast cancer cell line, KPL-1 secretes tumour-associated antigens and grows rapidly in female athymic nude mice. Br J Cancer 71: 845-853, 1995 .

17. Pham NA, Jacobberger JW, Schimmer AD, Cao P, Gronda M and Hedley DW: The dietary isothiocyanate sulforaphane targets pathways of apoptosis, cell cycle arrest, and oxidative stress in human pancreatic cancer cells and inhibits tumor growth in severe combined immunodeficient mice. Mol Cancer Ther 3: 1239-1248, 2004.

18. Matsui TA, Murata H, Sakabe T, Sowa Y, Horie N, Nakanishi R, Sakai T and Kubo T: Sulforaphane induces cell cycle arrest and apoptosis in murine osteosarcoma cells in vitro and inhibits tumor growth in vivo. Oncol Rep 18: 1263-1268, 2007.

19. Singh AV, Xiao D, Lew KL, Dhir R and Singh SV: Sulforaphane induces caspase-mediated apoptosis in cultured PC-3 human prostate cancer cells and retards growth of PC-3 xenografts in vivo. Carcinogenesis 25: 83-90, 2004

20. Myzak MC, Tong P, Dashwood WM, Dashwood RH and Ho E: Sulforaphane retards the growth of human PC-3 xenografts and inhibits HDAC activity in human subjects. Exp Biol Med (Maywood) 232: 227-234, 2007.

21. Cho NP, Han HS, Leem DH, Choi IS, Jung JY, Kim HJ, Moon KS, Choi KH, Soh Y, Kong G, Cho SD and Choi SH: Sulforaphane enhances caspase-dependent apoptosis through inhibition of cyclooxygenase- 2 expression in human oral squamous carcinoma cells and nude mouse xenograft model. Oral Oncol 45: 654-660, 2009.

22. Jackson SJ and Singletary KW: Sulforaphane: a naturally occurring mammary carcinoma mitotic inhibitor, which disrupts tubulin polymerization. Carcinogenesis 25: 219-227, 2004.

23. Shankar S, Ganapathy S and Srivastava RK: Sulforaphane enhances the therapeutic potential of TRAIL in prostate cancer orthotopic model through regulation of apoptosis, metastasis, and angiogenesis. Clin Cancer Res 14: 6855-6866, 2008.

24. Singh SV, Warin R, Xiao D, Powolny AA, Stan SD, Arlotti JA, Zeng Y, Hahm ER, Marynowski SW, Bommareddy A, Desai D, Amin S, Parise RA, Beumer JH and Chambers WH: Sulforaphane inhibits prostate carcinogenesis and pulmonary metastasis in TRAMP mice in association with increased cytotoxicity of natural killer cells. Cancer Res 69: 2117-2125, 2009.

25. Thejass P and Kuttan G: Antimetastatic activity of Sulforaphane. Life Sci 78: 3043-3050, 2006 